\title{
Preliminary Study of the Effect of Tourism Activities on Litter Pollution: a Case Study on Padar Island, Komodo National Park, Indonesia
}

\author{
Muhammad Reza Cordova ${ }^{1 *}$, Triyoni Purbonegoro', Rachma Puspitasari', \\ Riyana Subandi', Muhammad Taufik Kaisupy', Singgih Prasetyo Adi Wibowo', \\ Nurjamin', Suparmo', Serly Sapulete' \\ 1 Research Center for Oceanography-Indonesian Institute of Sciences, Jl. Pasir Putih 1 No. 1, Jakarta, Indonesia \\ * Corresponding author's email: muhammad.reza.cordova@lipi.go.id
}

\begin{abstract}
Tourism is a significant socioeconomic activity in a coastal country such as Indonesia. However, it degrades the ecosystem quality when the increasing litter pollution is poorly managed in the marine tourism area. The purpose of this research was to assess the impact of tourism on the litter pollution on the Padar Island, Komodo National Park, Indonesia, specifically on the hiking track. According to the performed investigation, plastic litter was discovered dominant on the Padar Island (131 of 146 items). It was found that filter cigarette butts (49 items, 33.56\%), candy wrapper (18 items, 12.33\%), wet tissue/wet wipes (17 items, 11.64\%) and outsole from shoe/sandals (13 items, $8.90 \%$ ), dominated the litter collected. Smoking activity, food and beverage consumption, and hiking activity are all examples of activities that may result in litter from visitors in this national park area. Tourism impacts the litter pollution in the Padar Island hiking trail. Therefore, more robust awareness strategies and controls are required to reduce the litter pollution and prevent further consequences.
\end{abstract}

Keywords: litter, tourism, hiking track, Padar Island, Komodo National Park, Indonesia.

\section{INTRODUCTION}

Human populations benefit from marine and coastal ecosystems, because they provide environmental goods and services that improve their well-being and promote their socioeconomic development [Hattam et al., 2015]. However, the environmental quality of ecosystems has deteriorated as a result of poor waste management and social and economic activities common to coastal populations, such as tourism, fishing, and trade, putting ecosystem services in jeopardy [Lu et al., 2018]. Marine litter, defined as all manufactured solid materials discarded or abandoned in the marine and coastal environment [GESAMP, 2015], is one of the pollutants produced by socioeconomic activities. Plastics are the most abundant marine litter materials due to their high production, use, and environmental persistence [Cordova, 2020]. According to many studies, unreliable litter management has negative environmental consequences [Cordova and Nurhati, 2019]. Litter, for example, creates a mess and an unpleasant odor in the visual and environment, negatively impacting the tourist satisfaction and the local tourism economy. Litter may also contaminate water and soil, and harm wildlife by increasing its reliance on litter as a food source as well as endanger tourist health by increasing the number of bees, flies, and other pesky insects [Cingolani et al., 2016]. Moreover, marine litter is a significant global issue because of its aesthetic, economic, and ecological consequences [Cordova, 2020; Gall and Thompson, 2015; Iskandar et al., 2021].

Tourism is a significant source of revenue for coastal communities all over the world [Ghosh, 2011]. However, vast tourism activity in the marine and coastal ecosystems, such as in remote marine tourism areas, has a severe impact to the ecosystem quality [Garcés-Ordóñez et al., 2020]. 
Among the environmental pressures caused by tourists, is marine litter. Tourism litter management has become an ever-growing problem in the world from a sustainability standpoint [Arbulú et al., 2016; Cingolani et al., 2016]. Particularly in remote marine tourism areas that have hiking tracks, the topographical situations are challenging and the traffic in remote area regions is uncomfortable. This condition leads to the difficulty of collecting litter and transportation on a hiking track [Hu et al., 2018]. This situation has been reported from a variety of tourist destinations around the world [Cordova et al., 2020b; Grelaud and Ziveri, 2020; Pervez et al., 2020; Silva et al., 2018]. Understanding the variation and interactions of marine litter pollution in tourist areas is critical for developing practical solutions according to the country's specific circumstances.

Komodo National Park is one of the most promising tourism destinations. With its unique qualities, such as the Komodo dragon habitat and beautiful and exotic marine life, the island is one of Indonesia's and the world's most promising tourism destinations [Kania, 2012]. Komodo National Park is an Indonesian national park located in the Lesser Sunda Islands, on the border between East and West Nusa Tenggara provinces. Komodo National Park was established in 1980 and had a total area of $1,733 \mathrm{~km}^{2}$ to protect the Komodo dragon, the world's largest lizard, endemic to the islands of Komodo, Rinca, Flores, and Gili Motang. Komodo National Park encompasses three larger islands, Komodo, Padar, Rinca, and 26 smaller ones. This national park is under management authority by the Ministry of Environment and Forestry of The Republic of Indonesia.

As one of the mainstay tourist destinations in Indonesia, Komodo National Park is visited by more than 170,000 tourists, a double increase from 2014 to 2018 [BPS Kabupaten Manggarai Barat, 2020]. The tourists visiting Komodo National Park will also visit Padar Island. Increased tourist visits will increase the level of the community's economy [Kiessling et al., 2017; Loizidou et al., 2018]. However, tourism is one of the most significant sources of marine pollution, as a large portion of the solid waste generated by visitors remains in the tourism area, polluting the environment and increasing cleaning costs [Kiessling et al., 2017; Loizidou et al., 2018]. This research was a preliminary study conducted to analyze the litter found on the hiking track on Padar Island, which is the most visited area there. This study aimed to assess the impact of tourism activity on litter pollution on the hiking track on Padar Island. The main research questions were "what are the main category, possible sources and composition of litter on the tourist area of hiking track on Padar Island?". This preliminary research contributes to the current knowledge about the qualitative and quantitative characteristics of marine litter in remote marine tourism areas, which is necessary for developing litter pollution prevention and reduction strategies in order to keep Komodo National Park, as well as other remote marine tourism areas around the world, in satisfactory quality.

\section{METHODOLOGY}

The research was conducted in Padar Island, the third-largest island in the Komodo National Park area \& part of the UNESCO World Heritage Site, on 24 July 2019. In 1986, the national park was declared a UNESCO World Heritage Site and a Man and Biosphere Reserve [Widaningrum and Damanik, 2016]. Padar is positioned between the Komodo and Rinca islands. The island's topography is rugged, with steep volcanic mountains and hills facing against deep bays. The main attraction of Padar Island is its panorama from the top of the hill. The hills have some slopes of more than 45 degrees. Although the data on the number of visitors for the whole National Park, particularly for Padar Island hiking track, is unavailable, the number of tourists in the Padar Island area of around $14.09 \mathrm{~km}^{2}$ was estimated at approximately 400-600 tourists daily the period in 2018. There is only one trash can near the port and ticket booth. The officer stated that the trash can is only for the garbage from outside Padar Island and it is not allowed to bring products that produce litter on the hiking track.

Sampling was undertaken on a hiking track in the south of the island. Litter was collected by adapting the litter line transect from marine litter guidelines and several studies [Cheshire et al., 2009; Cordova et al., 2020a; GESAMP, 2019; Lippiatt et al., 2013]. Sampling was done by walking along the $1014.26 \mathrm{~m}$ hiking track (Fig. 1). A litter with a size greater than $2.5 \mathrm{~cm}$ on a hiking track with an average track width of $4 \mathrm{~m}$ (area of observation $4057.04 \mathrm{~m}^{2}$ ), were manually collected. All of the collected material was washed dried in the sun to ensure that no sand was present. Following that, each item was counted and classified 


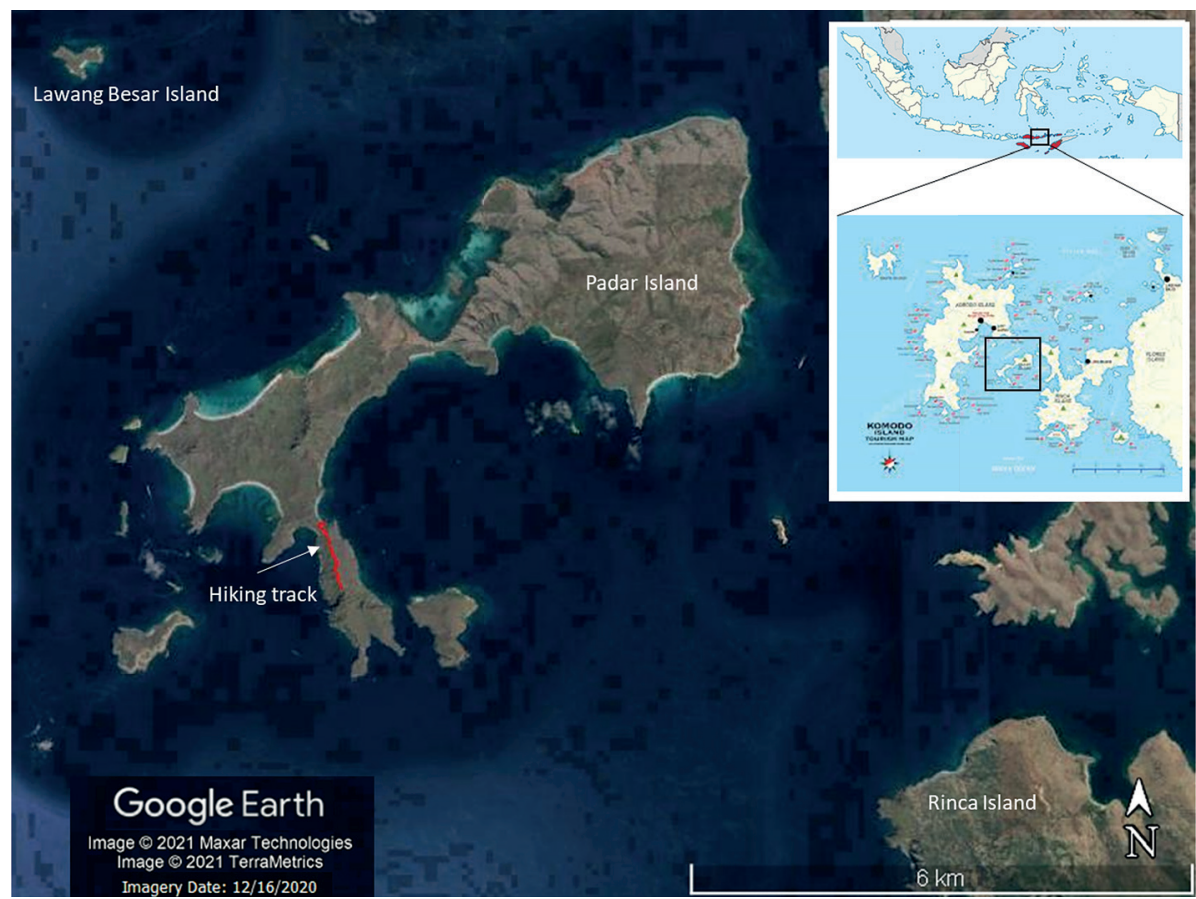

Figure 1. Map of sampling location in Padar Island, Komodo National Park. The Red line showed the hiking track area

according to its composition. The litter collected were measured and categorized by macro litter size classes with size between $2.5 \mathrm{~cm}$ to $100 \mathrm{~cm}$ [Cordova, 2020; Cordova et al., 2020a; GESAMP, 2019]. The litter obtained and included in the plastic category was analyzed for its chemical composition with Fourier transform infrared spectroscopy (Thermo Scientific Nicolet ${ }^{\mathrm{TM}}$ iS5 with diamond Attenuated Total Reflectance). Given that FTIR spectroscopy was used to analyze molecular vibrations, it was possible to determine that the authors were looking at a polymer by the presence of a prominent peak, which was previously identified [Cordova et al., 2018, 2020b, 2021; Purwiyanto et al., 2020; Suteja et al., 2021].

\section{RESULTS}

A total of 146 litter items were collected during a single sampling period on the Padar Island hiking track (Table 1). All of the litter collected was macro litter, with mean densities of 0.14 items per-m $\left(0.04\right.$ items per- $\left.\mathrm{m}^{2}\right)$. Plastic made up the majority of the litter, which was the most abundant material discovered. Plastics accounted for 131 items (nearly $90 \%$ of all collected litter), with an average of 0.13 items per-m ( 0.03 items per- $\left.\mathrm{m}^{2}\right)$. Twelve types of plastics were found at the hiking track of Padar Island. Among these types, four represented $66.44 \%$ of all items (Table 1): filter cigarette butts (49 items, 33.56\%), candy wrapper (18 items, 12.33\%), wet tissue/ wet wipes (17 items, 11.64\%) and outsole from shoe/sandals (13 items, 8.90\%). Meanwhile, three non-plastic types (tissue paper, clove cigarette butts and leftovers food) represent $10.27 \%$ of all categories, with percentages of $6.85 \%$, $1.37 \%$ and $2.05 \%$, respectively.

Cigarette butt filters were the most common type of litter. On the hiking trail from start to finish, one cigarette butt was found every $19.89 \mathrm{~m}$ $\left(79.55 \mathrm{~m}^{2}\right)$, followed by tissue found every 37.57 $\mathrm{m}\left(150 \mathrm{~m}^{2}\right)$ and candy wrappers found every 56.35 $\mathrm{m}\left(225.39 \mathrm{~m}^{2}\right)$. Cigarette butts with filters $(20.70$ $\mathrm{m}$ or $\left.82.80 \mathrm{~m}^{2}\right)$ and wet tissue $(59.66 \mathrm{~m}$ or 238.65 $\mathrm{m}^{2}$ ) were more commonly found than cloves cigarette butts (collected every $507.13 \mathrm{~m}$ or every $2028.52 \mathrm{~m}^{2}$ ) and paper tissue (101.43 $\mathrm{m}$ or 405.70 $\mathrm{m}^{2}$ ) in the lane Padar Island hiking track.

During the investigation into the possible sources of litter along the hiking trail on Padar Island, it was discovered that tourism was the most likely source of all litter (plastics and nonplastic). On the basis of the more detailed origin of the litter, the litter was divided as originating from the activity of smoking, food and beverage, and others. The smoking activity was the 
Table 1. Litter category found in hiking track of Padar Island, Komodo National Park

\begin{tabular}{|c|l|c|c|c|c|c|c|}
\hline \multirow{2}{*}{ No } & \multirow{2}{*}{ Litter category } & \multirow{2}{*}{ Item found } & \multirow{2}{*}{$\%$} & \multicolumn{2}{|c|}{ Litter average } & \multicolumn{2}{|c|}{ Items of litter found every } \\
\cline { 5 - 8 } & & & per-m & per-m $\mathrm{m}^{2}$ & \multicolumn{2}{c|}{$\mathrm{m}$} & $\mathrm{m}^{2}$ \\
\hline 1 & Filter cigarette butts & 49 & 33.56 & 0.0483 & 0.0121 & 20.70 & 82.80 \\
\hline 2 & Candy wrapper & 18 & 12.33 & 0.0177 & 0.0044 & 56.35 & 225.39 \\
\hline 3 & Wet tissue/wet wipes & 17 & 11.64 & 0.0168 & 0.0042 & 59.66 & 238.65 \\
\hline 4 & Outsole from shoe/sandals & 13 & 8.90 & 0.0128 & 0.0032 & 78.02 & 312.08 \\
\hline 5 & Tissue paper & 10 & 6.85 & 0.0099 & 0.0025 & 101.43 & 405.70 \\
\hline 6 & Bottle cap & 7 & 4.79 & 0.0069 & 0.0017 & 144.89 & 579.58 \\
\hline 7 & Plastic snacks wrappers & 6 & 4.11 & 0.0059 & 0.0015 & 169.04 & 676.17 \\
\hline 8 & Mineral water bottle & 6 & 4.11 & 0.0059 & 0.0015 & 169.04 & 676.17 \\
\hline 9 & Plastic cups & 5 & 3.42 & 0.0049 & 0.0012 & 202.85 & 811.41 \\
\hline 10 & Plastic bag & 4 & 2.74 & 0.0039 & 0.0010 & 253.57 & 1014.26 \\
\hline 11 & Plastic sachet & 3 & 2.05 & 0.0030 & 0.0007 & 338.09 & 1352.35 \\
\hline 12 & Leftovers food & 3 & 2.05 & 0.0030 & 0.0007 & 338.09 & 1352.35 \\
\hline 13 & Cigarette lighter & 2 & 1.37 & 0.0020 & 0.0005 & 507.13 & 2028.52 \\
\hline 14 & Clove cigarette butts & 2 & 1.37 & 0.0020 & 0.0005 & 507.13 & 2028.52 \\
\hline 15 & Clothes & 1 & 0.68 & 0.0010 & 0.0002 & 1014.26 & 4057.04 \\
\hline
\end{tabular}

most dominant source of litter found, as much as $36.30 \%$. The waste from a smoking activity is cigarette butts (filter and cloves) and cigarette lighter. The activities from food and beverage were the most abundant sources collected, such as candy wrappers, wet tissues, bottle caps, plastic snacks wrappers, mineral water bottles, plastic cups, plastic bags, plastic sachets, and food leftovers as $35.62 \%$. Other activities that were producing litter were suspected to be the activities directly related to hiking activities, with the type of litter such as tissue (wet and paper), outsole from shoes or sandals and clothes by $28.08 \%$. It is suspected that the source of the litter on the hiking track comes from visitors, in contrast to the litter found on the beach, which can be carried away by ocean currents.

All litter categorized as plastic were analyzed for their chemical composition. There were 14 polymer types in total (Fig. 2), dominated by cellulose acetate group (37.40\%), followed by polypropylene (18.32\%), polyethylene $(17.56 \%)$, polyester group $(10.69 \%)$, polyethylene terephthalate $(9.16 \%)$, polyurethane $(3.82 \%)$, poly (butylene) terephthalate (1.53\%), and styrene/acrylonitrile copolymer (1.53\%). The polymer cellulose acetate group, which dominates the type of polymer in this preliminary study, comes from the cigarette butt filter. The cellulose acetate group
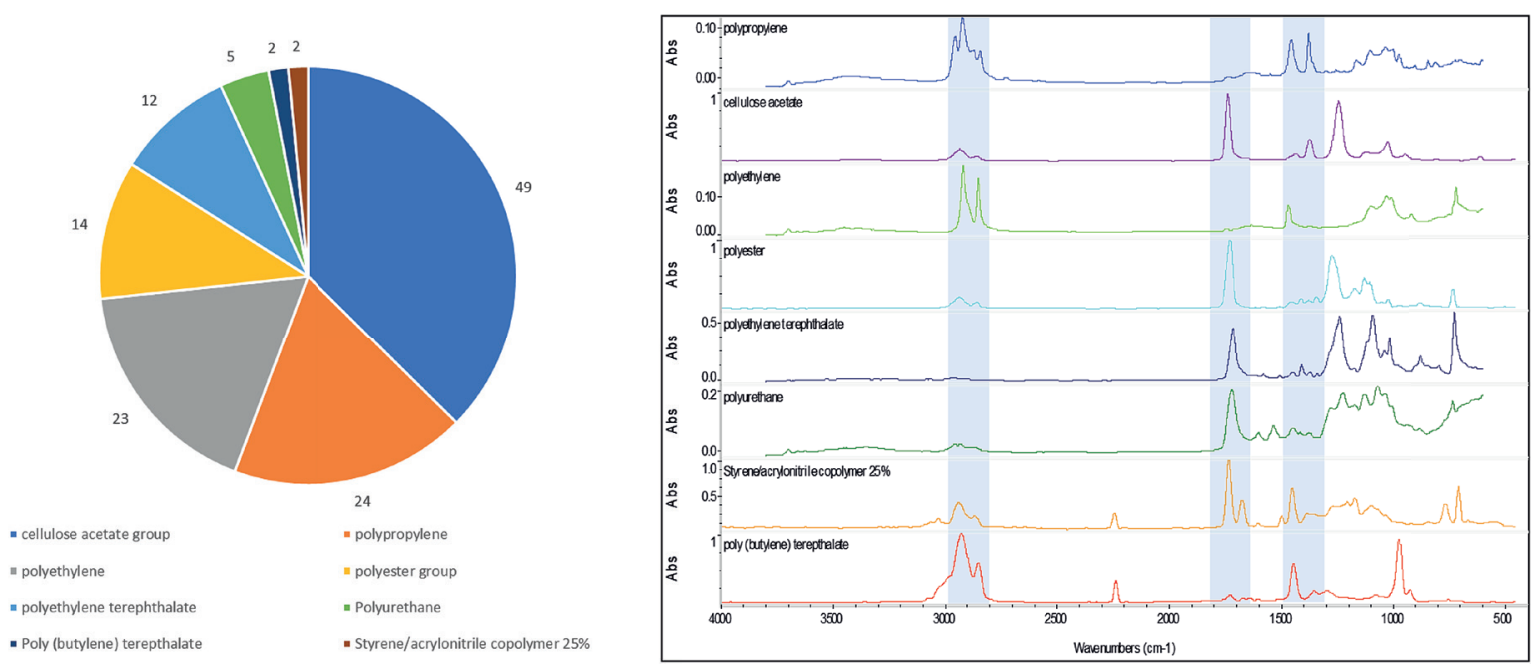

Figure 2. Chemical analysis and identification from litter in hiking track of Padar Island, Komodo National Park 
consists of cellulose triacetate, cellulose acetate butyrate, and cellulose acetate. Polypropylene in this study came from a candy wrapper, wet tissue/ wet wipes, plastic snacks wrappers, plastic cups, plastic bags and plastic sachets. Polyethylene polymers are found in candy wrappers, outsole from shoes/sandals, bottle caps and plastic bags. Wet tissue/wet wipes and discarded clothes are the contributors to the polymer type of polyester. Candy wrappers and plastic bottles are the contributors to the polymer type polyethylene terephthalate (PET). Polyurethane is found in the outsole of shoes/sandals. Poly (butylene) terephthalate is part of the bottle cap. Cigarette lighter has a styrene/acrylonitrile copolymer type polymer.

\section{DISCUSSION}

The obtained results demonstrated an association between visitors walking on hiking tracks on Padar Island and the litter found. However, because data collection was only carried out once, no statistical analysis could be performed to examine the occurrence of litter on the Padar Island hiking track. Furthermore, regular monitoring can be carried out to see the impact of visitors on the litter found to provide advice regarding the litter management on Padar Island and in Komodo National Park. It was found that smoking, food and beverages, and hiking activities resulted in a higher amount of litter.

The plastic and non-plastic litter carried and discarded by visitors can cause environmental disturbances in Komodo National Park. Pickering et al. [2011] and Wolf et al. [2012] stated that hiking activities would increase litter, reducing the height of the vegetation and changes in the composition of the foliage. The plastic litter found dominant in this area was consistent with recent case studies from marine tourism areas, particularly in beach areas, namely single-use plastic from food and beverages and also smoking activities [Cingolani et al., 2016; Kiessling et al., 2017; Loizidou et al., 2018; Syakti et al., 2019]. Plastics account for the vast majority of litter found along coastlines, corresponding to more than $80 \%$ in some areas [Lechthaler et al., 2020; Rech et al., 2018]. As it was found in this study, single-use plastics are abundant in marine environments, linked mainly to touristic and recreational activities [Newman et al., 2015; Zhao et al., 2015]. The plastic litter presence can have various negative consequences for a wide range of species, habitats, and human activities [Cordova, 2020]. Plastics are also involved in the majority of interactions between litter and marine organism [Cordova et al., 2020b].

Plastic packages related to food and beverages, quite a lot of which were found in this area, are included in the single-use packages category. According to Law [2017], this is also a worldwide litter pattern in marine tourism and marine protected areas. The packaging made of plastic is widely used in the transportation of products because of its convenience and durability [de Ramos et al., 2021]. Plastic packaging made up nearly half of all plastic waste generated globally in 2015 [UNEP, 2018], and because of its lightweight, it can be easily transported by the environmental elements (i.e. wind, rain, waves and currents), eventually ending up on beaches and in the ocean [UNEP, 2018].

The type of litter category most commonly found on the hiking track on Padar Island was cigarettes butts, wet tissue or wet wipes, and outsole from shoes/sandals. This result was similar to the results of a research study by Grillo et al. [2021] in a remote oceanic marine protected area in the tropical southwest Atlantic. Personal litter, such as cigarette butts, is considered the most common type of litter globally [Novotny and Slaughter, 2014]. These litter residues are insignificant in size, but they are produced in large quantities [Loizidou et al., 2018; MartinezRibes et al., 2007]. It is common for cigarette butts to be one of the top three most abundant items collected during beach litter surveys and island clean-up events [Grillo and Mello, 2021; Martinez-Ribes et al., 2007; Wilson and Verlis, 2017]. The presence of cigarette butts suggests that they might have been thrown by the tourists walking on the hiking track. Padar Island is a conservation area to protect the Komodo Dragon, which should not have the activities that produce waste. However, in this area, the dominance of cigarette butts was found. Cigarettes contain more than 5000 different chemical compounds [Araújo and Costa, 2019]; 150 of these additives are considered highly toxic, primarily because of their carcinogenic and mutagenic potential [Slaughter et al., 2011]. After cigarettes are burned and smoked, the compounds with the most significant toxicity are primarily concentrated in tobacco residues and filter cigarettes butts [Barnes, 2011; Slaughter et al., 2011]. 
Upon leaching by rainwater, these compounds can contaminate the soil, where they are then superficially transported to aquatic environments, where the compounds can be detected [Slaughter et al., 2011]. This is cause for concern, given the cigarette butts are a ubiquitous, harmful, and recalcitrant type of marine litter that requires immediate attention from manufacturers, users, authorities, and the general public in order to prevent the marine biota from ingesting the butts and water pollution as a result of the leachate [Araújo and Costa, 2019]. Public ashtrays at viewpoints (especially prior to ticketing) and the allocation of portable ashtrays before the hiking trail could reduce the number of cigarette butts littered in these areas and raise the smokers' awareness of their environmental impact as polluters [Araújo and Costa, 2019].

Wet tissue or wet wipes are included in the category of the non-woven textile industry, used for cleaning or disinfecting. The wet tissue litter collected in this study was used to clean the sweat that came out after walking on the hiking track on Padar Island. It is estimated that the number of wet wipes washing up on the shores of the United Kingdom has increased by $94 \%$ since 2017 and by $400 \%$ over the last decade [Pantoja Munoz et al., 2018]. In Indonesia itself, there has been no special attention related to wet wipes. In fact, wet tissue litter has a harmful impact on the environment. Wet wipes can be a source of microplastics for the marine environment [McCoy et al., 2020; Ó Briain et al., 2020]. Moreover, low Asian clam populations are associated with high densities of wet wipes [McCoy et al., 2020]. Careless wet tissue disposal in the Komodo National Park area may affect the organism in this area, including the Komodo Dragon.

Another dominant litter source found in this study was the outsole from shoes/sandals. Shoe wear particles have the potential to be a significant source of contamination on hiking trails [Forster et al., 2020]. Hiking boots and shoes and trail running shoes generate the most significant amount of friction and abrasive force, with the highest rates of abrasion occurring during the first few hours of use [Ocif et al., 2004]. According to a Danish Environmental Protection Agency report, the total annual abrasion from shoe outsoles ranged between 100 and 1000 tonnes in Denmark alone during 2015 [Lassen et al., 2015]. Moreover, according to a German study, shoe outsole wear and tear was the seventh most significant contributor to microplastics in the country [Forster et al., 2020]. The research related to shoe wear particles to friction and abrasive force, mainly to hiking tracks, is still not available, so extensive research is needed to see the impact of plastic litter on and adjacent to tracks in the marine protected area.

The collected non-plastic litter (tissue paper, clove cigarette butts and leftovers food) represents $10.27 \%$ associated with tourism activities, with an average of 0.015 items per-m or 0.004 items per- $\mathrm{m}^{2}$ ). All non-plastic litter found was organic litter (not like glass and metal) which would be decomposed by microbes. Thus, the number was rather inadequate; however, it can contribute to nutrient imbalances in large quantities, resulting in deteriorating soil quality, water pollution, and air pollution in some cases [Čičková et al., 2015; Westerman and Bicudo, 2005].

According to the findings of Käppler et al. [2015] and Löder et al. [2015], plastic litter identification from Padar Island accomplished by measuring vibrations (Fig. 2) in the band regions $2780-2980 \mathrm{~cm}^{-1}\left(\mathrm{CH} / \mathrm{CH}_{2} / \mathrm{CH}_{3}\right.$ groups stretching vibrations), $1740-1800 \mathrm{~cm}^{-1}(\mathrm{C}=\mathrm{O}$ stretching vibration $), 1670-1760 \mathrm{~cm}^{-1}(\mathrm{C}=\mathrm{O}$ stretching vibration), $1400-1480 \mathrm{~cm}^{-1}\left(\mathrm{CH}_{2}\right.$ bending vibration) and at band region 1174-1087 $\mathrm{cm}^{-1}$ (CF2 stretching vibration). On the basis of the chemical composition analysis, the polymer found in this study was thought to have been exposed to environmental conditions such as direct sunlight, wind and friction against litter on the hiking track in Padar Island. The presence of a peak that appears in the absorbance region between $1700-1800 \mathrm{~cm}^{-1}$ indicates the oxidation of the carbonyl group [Fotopoulou and Karapanagioti, 2015]. Syakti et al. [2017] stated that plastic litter made from polyethylene and polypropylene polymers that underwent oxidation was indicated by the presence of a peak in the FTIR analysis results in the band region of $1775 \mathrm{~cm}^{-1}$ or 1715 $\mathrm{cm}^{-1}$. Most of the plastic litter in this study identified as polyethylene and polypropylene ( 25 of $47,53.19 \%$ ) has been oxidized (Fig. 2). It was also found that the plastic litter (polyethylene and polypropylene) has an incomplete shape and faded color. In this situation, a small number of chemicals may be drawn into the polymer and absorbed onto its surface [Syakti et al., 2017; Zhao et al., 2013]. 
The obtained results indicate that litter found on hiking tracks is closely related to visitors. However, because of the limited number of representatives, Komodo National Park is unlikely to have the resources to clean up litter along the hiking track. There have been clean-ups along the hiking track on Padar Island, but there was no quantitative data to back up these claims. Examining the presence of trash in the Komodo National Park may be beneficial in gaining a better understanding of the visitor-related impacts in the national park. Visitors' traces, such as the amount of litter left in the natural environment, are not only associated with a number of tourist arrivals but also found to correlate to personal behavior, as Muhar et al. [2002] mention in their study. This preliminary research needs to be continued in greater detail to answer the challenges in protected area management to understand the relationship between visitors and litter. In the future, periodic monitoring and analyzing the amount of trash in the hiking track can help identify the litter accumulation areas and promote an updated visitor management plans for the Komodo National Park, particularly for the litter from the tourism activity.

\section{CONCLUSIONS}

As a result of the conducted investigation, it was discovered that the plastic litter spread in hiking track on Padar Island, with cigarettes butts, candy wrapper, wet tissue/wet wipes and outsole from shoe/sandals being dominant. This litter might originate from the visitors who engage in smoking, food and beverages, and hiking activity. Without proper management, the litter from tourist activities can disrupt the life of organisms in the national park. As long as there are ongoing efforts to monitor visitor and litter impact distributions in Komodo National Park, it will be possible to concentrate the management efforts on the areas where resource and visitor understanding protections are most required.

\section{Acknowledgements}

The authors would like to thank Komodo National Park staff and forest ranger, especially Mr Ikhwan Syahri and Ms Maria Panggur. This study was fully funded by LIPI's COREMAP CTI 2021-2022 (17/A/DK/2021) coordinate by Triyoni Purbonegoro.

\section{REFERENCES}

1. Araújo, M.C.B. \& Costa, M.F. (2019). A critical review of the issue of cigarette butt pollution in coastal environments. Environmental Research, 172, 137-149.

2. Arbulú, I., Lozano, J., Rey-Maquieira, J. (2016). The challenges of municipal solid waste management systems provided by public-private partnerships in mature tourist destinations: The case of Mallorca. Waste Management, 51, 252-258.

3. Barnes, R.L. (2011). "Regulating the disposal of cigarette butts as toxic hazardous waste." Tobacco Control, 20(Suppl 1), i45 LP-i48.

4. BPS Kabupaten Manggarai Barat. (2020). Kabupaten Manggarai Barat dalam angka, 2019.

5. Cheshire, A.C., Adler, E., Barbière, J., Cohen, Y., Evans, S., Jarayabhand, S., Jeftic, L., Jung, R.T., Kinsey, S., Kusui, E.T., Lavine, I., Manyara, P., Oosterbaan, L., Pereira, M.A., Sheavly, S., Tkalin, A., Varadarajan, S., Wenneker, B., Westphalen, G. (2009). UNEP/IOC Guidelines on Survey and Monitoring of Marine Litter. UNEP Regional Seas Reports and Studies No. 186. Nairobi, Kenya.

6. Čičková, H., Newton, G.L., Lacy, R.C., Kozánek, M. (2015). The use of fly larvae for organic waste treatment. Waste Management, 35, 68-80.

7. Cingolani, A.M., Barberá, I., Renison, D., Barri, F.R. (2016). Can persuasive and demonstrative messages to visitors reduce littering in river beaches? Waste Management, 58, 34-40.

8. Cordova, M.R. (2020). Marine Plastic Debris: Distribution, Abundance, and Impact on Our Seafood. Handbook of Research on Environmental and Human Health Impacts of Plastic Pollution, K.A. Wani, L. Ariana, and S.M. Zuber, eds., IGI Global, Hershey, PA, 94-121.

9. Cordova, M.R., Hadi, T.A., Prayudha, B. (2018). Occurrence and abundance of microplastics in coral reef sediment : a case study in Sekotong, LombokIndonesia. Advances in Environmental Sciences Bioflux, 10(1), 23-29.

10. Cordova, M.R. \& Nurhati, I.S. (2019). Major sources and monthly variations in the release of landderived marine debris from the Greater Jakarta area, Indonesia. Scientific Reports, 9(1), 18730.

11. Cordova, M.R., Purbonegoro, T., Puspitasari, R., Subandi, R., Kaisupy, M.T., Wibowo, S.P. A., Nurjamin, N., Suparmo, S., Sapulete, S. (2020a). Transboundary debris in Indonesian frontier and outermost island: A preliminary case study of Nipah Island. OLDI (Oseanologi dan Limnologi di Indonesia), 5(3), 171.

12. Cordova, M.R., Riani, E., Shiomoto, A. (2020b). Microplastics ingestion by blue panchax fish (Aplocheilus sp.) from Ciliwung Estuary, Jakarta, Indonesia. Marine Pollution Bulletin, 161, 111763. 
13. Cordova, M.R., Ulumuddin, Y.I., Purbonegoro, T., Shiomoto, A. (2021). Characterization of microplastics in mangrove sediment of Muara Angke Wildlife Reserve, Indonesia. Marine Pollution Bulletin, 163, 112012.

14. Forster, N.A., Tighe, M.K., Wilson, S.C. (2020). Microplastics in soils of wilderness areas: What is the significance of outdoor clothing and footwear? Geoderma, 378.

15. Fotopoulou, K.N., and Karapanagioti, H.K. (2015). "Surface properties of beached plastics." Environmental Science and Pollution Research, 22(14), 11022-11032.

16. Gall, S.C., and Thompson, R.C. (2015). The impact of debris on marine life. Marine Pollution Bulletin, 92(1-2), 170-179.

17. Garcés-Ordóñez, O., Espinosa Díaz, L.F., Pereira Cardoso, R., Costa Muniz, M. (2020). The impact of tourism on marine litter pollution on Santa Marta beaches, Colombian Caribbean. Marine Pollution Bulletin, 160.

18. GESAMP. (2015). Sources, fate and effects of microplastics in the marine environment: a global assessment". Reports and Studies GESAMP - Joint Group of Experts on the Scientific Aspects of Marine Environmental Protection.

19. GESAMP. (2019). Guidelines for the monitoring and assessment of plastic litter in the ocean (Kershaw P.J., Turra A. and Galgani F. editors). GESAMP.

20. Ghosh, T. (2011). Coastal Tourism: Opportunity and Sustainability. Journal of Sustainable Development, 4(6).

21. Grelaud, M. \& Ziveri, P. (2020). The generation of marine litter in Mediterranean island beaches as an effect of tourism and its mitigation. Scientific Reports, 10(1).

22. Grillo, A.C. \& Mello, T. J. (2021). Marine debris in the Fernando de Noronha Archipelago, a remote oceanic marine protected area in tropical SW Atlantic. Marine Pollution Bulletin, 164.

23. Hattam, C., Atkins, J.P., Beaumont, N., Börger, T., Böhnke-Henrichs, A., Burdon, D., De Groot, R., Hoefnagel, E., Nunes, P.A.L.D., Piwowarczyk, J., Sastre, S., Austen, M.C. (2015). Marine ecosystem services: Linking indicators to their classification. Ecological Indicators, 49, 61-75.

24. Hu, H., Zhang, J., Chu, G., Yang, J., Yu, P. (2018). Factors influencing tourists' litter management behavior in mountainous tourism areas in China. Waste Management, 79, 273-286.

25. Iskandar, M.R., Surinati, D., Cordova, M.R., Siong, K. (2021). Pathways of floating marine debris in Jakarta Bay, Indonesia. Marine Pollution Bulletin, 169.

26. Kania, D. (2012). The Role of New Media in Facilitating Entrepreneurship in Tourism - Case Study: Promoting Komodo Island in East Nusa Tenggara.
Jurnal ULTIMA Comm, 4(1), 63-72.

27. Käppler, A., Windrich, F., Löder, M.G.J., Malanin, M., Fischer, D., Labrenz, M., Eichhorn, K. J., Voit, B. (2015). Identification of microplastics by FTIR and Raman microscopy: a novel silicon filter substrate opens the important spectral range below $1300 \mathrm{~cm}^{-1}$ for FTIR transmission measurements. Analytical and bioanalytical chemistry, 407(22), 6791-6801.

28. Kiessling, T., Salas, S., Mutafoglu, K., Thiel, M. (2017). Who cares about dirty beaches? Evaluating environmental awareness and action on coastal litter in Chile. Ocean and Coastal Management, 137, 82-95.

29. Lassen, C., Hansen, S.F., Magnusson, K., Hartmann, N.B., Rehne Jensen, P., Nielsen, T.G., Brinch, A. (2015). Microplastics - Occurrence, effects and sources of releases to the environment in Denmark. Danish Environmental Protection Agency.

30. Law, K.L. (2017). Plastics in the Marine Environment. Annual Review of Marine Science. Annual Reviews, 9(1), 205-229.

31. Lechthaler, S., Waldschläger, K., Stauch, G., Schüttrumpf, H. (2020). The way of macroplastic through the environment. Environments - MDPI, 7(10), $1-30$.

32. Lippiatt, S., Opfer, S., Arthur, C. (2013). Marine Debris Monitoring and Assessment. NOAA Technical Memorandum NOS-OR\&R-46. NOAA Technical Memorandum NOS-OR\&R-46, (November), 82.

33. Löder, M.G.J., Kuczera, M., Mintenig, S., Lorenz, C., Gerdts, G. (2015). Focal plane array detectorbased micro-Fourier-transform infrared imaging for the analysis of microplastics in environmental samples. Environmental Chemistry, 12(5), 563-581.

34. Loizidou, X.I., Loizides, M.I., Orthodoxou, D.L. (2018). Persistent marine litter: small plastics and cigarette butts remain on beaches after organized beach cleanups. Environmental Monitoring and Assessment, 190(7).

35. Lu, Y., Yuan, J., Lu, X., Su, C., Zhang, Y., Wang, C., Cao, X., Li, Q., Su, J., Ittekkot, V., Garbutt, R. A., Bush, S., Fletcher, S., Wagey, T., Kachur, A., Sweijd, N. (2018). Major threats of pollution and climate change to global coastal ecosystems and enhanced management for sustainability. Environmental Pollution, 239, 670-680.

36. Martinez-Ribes, L., Basterretxea, G., Palmer, M., Tintoré, J. (2007). Origin and abundance of beach debris in the Balearic Islands. Scientia Marina, 71(2), 305-314.

37. McCoy, K.A., Hodgson, D.J., Clark, P.F., Morritt, D. (2020). The effects of wet wipe pollution on the Asian clam, Corbicula fluminea (Mollusca: Bivalvia) in the River Thames, London. Environmental Pollution, 264.

38. Muhar, A., Arnberger, A., Brandenburg, C. (2002). Methods for Visitor Monitoring in Recreational 
and Protected Areas: An Overview. Monitoring and Management of Visitor Flows in Recreational and Protected Areas, 1-6.

39. Newman, S., Watkins, E., Farmer, A., Brink, P. Ten, Schweitzer, J. P. (2015). The economics of marine litter. Marine Anthropogenic Litter.

40. Novotny, T.E., \& Slaughter, E. (2014). Tobacco Product Waste: An Environmental Approach to Reduce Tobacco Consumption. Current environmental health reports, 1(3), 208-216.

41. Ó Briain, O., Marques Mendes, A.R., McCarron, S., Healy, M.G., and Morrison, L. (2020). The role of wet wipes and sanitary towels as a source of white microplastic fibres in the marine environment. Water Research, 182.

42. Ocif, J., Cappaert, J., Rich, B. (2004). A method for using an ultrasonic thickness gauge to assess outsole wear in running shoes. Proceedings of the IEEE Annual Northeast Bioengineering Conference, NEBEC, 174-175.

43. Pantoja Munoz, L., Gonzalez Baez, A., McKinney, D., Garelick, H. (2018). Characterisation of 'flushable' and 'non-flushable' commercial wet wipes using microRaman, FTIR spectroscopy and fluorescence microscopy: to flush or not to flush. Environmental Science and Pollution Research, 25(20), 20268-20279.

44. Pervez, R., Wang, Y., Ali, I., Ali, J., Ahmed, S. (2020). The analysis of the accumulation of solid waste debris in the summer season along the Shilaoren Beach Qingdao, China. Regional Studies in Marine Science, 34.

45. Pickering, C. M., Rossi, S., Barros, A. (2011). Assessing the impacts of mountain biking and hiking on subalpine grassland in australia using an experimental protocol. Journal of Environmental Management, 92(12), 3049-3057.

46. Purwiyanto, A. I. S., Suteja, Y., Trisno, Ningrum, P. S., Putri, W. A. E., Rozirwan, Agustriani, F., Fauziyah, Cordova, M. R., Koropitan, A.F. (2020). Concentration and adsorption of $\mathrm{Pb}$ and $\mathrm{Cu}$ in microplastics: Case study in aquatic environment. Marine Pollution Bulletin, 158, 111380.

47. De Ramos, B., Alencar, M.V., Rodrigues, F.L., Lacerda, A.L. de F., Proietti, M.C. (2021). Spatio-temporal characterization of litter at a touristic sandy beach in South Brazil. Environmental Pollution, 280.

48. Rech, S., Borrell Pichs, Y.J., García-Vazquez, E. (2018). Anthropogenic marine litter composition in coastal areas may be a predictor of potentially invasive rafting fauna. PLoS ONE, 13(1).
49. Silva, M.L. da, Castro, R.O., Sales, A.S., Araújo, F.V. de. (2018). Marine debris on beaches of Arraial do Cabo, RJ, Brazil: An important coastal tourist destination. Marine Pollution Bulletin, 130, 153-158.

50. Slaughter, E., Gersberg, R.M., Watanabe, K., Rudolph, J., Stransky, C., Novotny, T.E. (2011). Toxicity of cigarette butts, and their chemical components, to marine and freshwater fish. Tobacco Control, 20(Suppl 1), i25 LP-i29.

51. Suteja, Y., Atmadipoera, A.S., Riani, E., Nurjaya, I. W., Nugroho, D., Cordova, M.R. (2021). Spatial and temporal distribution of microplastic in surface water of tropical estuary: Case study in Benoa Bay, Bali, Indonesia. Marine Pollution Bulletin, 163, 111979.

52. Syakti, A.D., Bouhroum, R., Hidayati, N.V., Koenawan, C. J., Boulkamh, A., Sulistyo, I., Lebarillier, S., Akhlus, S., Doumenq, P., Wong-Wah-Chung, P. (2017). Beach macro-litter monitoring and floating microplastic in a coastal area of Indonesia. Marine Pollution Bulletin, 122(1-2), 217-225.

53. Syakti, A.D., Jacob, M., Birrien, T., Suhana, M.P., Aziz, M.Y., Salim, A., Doumenq, P., Louarn, G. (2019). Daily apportionment of stranded plastic debris in the Bintan Coastal area, Indonesia. Marine Pollution Bulletin, 149.

54. UNEP. (2018). Single-use Plastics - A Roadmap for Sustentability. United Nations Enviroment Program (UNEP).

55. Westerman, P.W. \& Bicudo, J.R. (2005). Management considerations for organic waste use in agriculture. Bioresource Technology, 96(2), 215-221.

56. Widaningrum, A. \& Damanik, J. (2016). Improving tourism destination governance: Case of Labuan Bajo City and the Komodo National Park, Indonesia. Social Sciences (Pakistan), 11(21), 5043-5051.

57. Wilson, S.P. \& Verlis, K.M. (2017). The ugly face of tourism: Marine debris pollution linked to visitation in the southern Great Barrier Reef, Australia. Marine Pollution Bulletin, 117(1-2), 239-246.

58. Wolf, I.D., Hagenloh, G., Croft, D.B. (2012). Visitor monitoring along roads and hiking trails: How to determine usage levels in tourist sites. Tourism Management, 33(1), 16-28.

59. Zhao, J., Yang, R., Yu, J. (2013). Interfacial effect on photo-oxidation of PP via model blends. Polymer Degradation and Stability, 98(10), 1981-1987.

60. Zhao, S., Zhu, L., Li, D. (2015). Characterization of small plastic debris on tourism beaches around the South China Sea. Regional Studies in Marine Science, 1, 55-62. 